\title{
Spaces of Sovereignty: A tale of an unrecognized Palestinian village in Israel
}

Figure 1: Demolition of a house, Dahmesh, 2006. Photography: Arafat Ismail

\section{Preface}

Informal housing environments, namely the construction of houses without acquiring building permits, are perceived as chaotic spaces of illegality, developing outside and against the formal planning system in Israel. Yet, as Ananya Roy (2011) suggests, such informal urban development cannot be viewed as external to the planning system, a matter that has been discussed by several researchers studying planning and legal geography in Israel (Kedar, 1998; Fenster. 2012; Yiftachel, 2006; 2009; Tzfadia and Yiftachel, 2014).The main argument raised by these scholars is that legal unrecognition of Palestinian habitat by the state causes informality, especially in peripheral areas outside the Israeli urban core, and mainly regarding the Bedouin settlement in the Negev (Weizman and Sheikh, 2015; Roded, 2012). Furthermore, as claimed by Yacobi (2009), informal housing production is a response to unrecognition which constitutes constant minority challenges to the prevailing order. This is expressed in the growing phenomenon of urban informality that emerges as a permanent feature of different cities in Israel, and becomes a central strategy of both ruling authorities and resisting, peripheral groups.In other words, policy-makers allow urban informality because it provides indirect and inexpensive rule of the 'ungovernable' (Roy, 2005). The tactic is avoidance and containment from a distance, but the result is the condemnation of large communities to un-serviced, deprived, and stigmatized urban fringes. In this way, urban informality emerges as a planning strategy; it allows the urban elites to represent municipal government as egalitarian, civil, and democratic, while at the same time, denying some urban residents basic rights and services in the locations into which they were forced. City and state elites draw legitimacy from this partial and distorted representation of planning as 'professional,' enabling the preservation of the privileged ethno-class strata, and a precarious maintenance of the system (Yacobi, 2009).

The case study that will be examined in this paper - the unrecognized Palestinian village of Dahmesh ${ }^{1}$ - is such a case of informal housing environment and can be read using these theoretical tools. Nevertheless, in this paper we wish to expend the discussion on informality by analyzing it from a different perspective and examining the role of the unrecognized village in 
the production of sovereignty. We have chosen a case study that is located at the heart of the Israeli metropolis. By doing so, we aim to delineate the Israeli territorial project as one thatinherently cannot be completed, as an ongoing process of production and re-production both of space and of sovereignty, and as a site for constant negotiation between everyday life and sovereign power. We will convey the case of the unrecognized village and will critically analyze the way sovereignty is constantly re-produced and re-approved by the refusal to make a final decision regarding the fate of this informal village. We will show how the legal discussion regarding Dahmesh is constructed in a way that produces a gap where sovereignty - as conceptualized by Carl Schmitt through its ability to suspend law -does not retreat to its potentiality and is constantly present in everyday life. In other words, sovereignty 'stretches' decision in order to maintain its presence in the political sphere.

Our analysis is rooted in critical theories, which refer to the Israeli planning framework through a settler colonial prism (Yacobi, 2009; Yiftachel, 2006). Settler colonialism denotes states where a new political order carrying the settlers' own sovereignty is constituted, while the settlers become a majority of the population and gain control over the land (Wolfe, 2006; Veracini, 2010). Within this framework, a hegemonic ethno-national group colonizes, appropriates and controls territory, producing contested spaces of structural instability, defined by Oren Yiftachel (2006) as ethnocracy, i.e. a distinct regime type established to enhance the expansion and control of a dominant ethno-nation in multi-ethnic territories. In such regimes, ethnicity, rather than citizenship, forms the main criteria for distributing power and resources. As a result, they typically display high levels of uneven ethnic segregation, inequality and exclusion.

Of particular relevance to this article is the fact that ethnocratic regimes can combine a degree of political openness and formal-democratic representation with political structures that facilitate the seizure of contested territory by a dominant ethno-national group. During this process, the dominant group appropriates state apparatuses, such as planning, while marginalizing peripheral ethnic and national minorities.

In the following section, we outline the chronology of the village of Dahmesh and the legal struggles surrounding its (un)recognition. In the second part of the paper we examine this case through Schmitt's conceptualisation of sovereign decision and present our main hypothesis. In the third part, we suggest a conceptualization of the type of spaces created by this sovereign practice, and in the fourth part we offer an analysis of these spaces in the context of Schmitt's 
debate with Hans Kelzen's concept of the 'Ground Norm'. Our conclusion and discussion offers some preliminary insights regarding the role of (in) decision in civil resistance.

Figure 2: An aerial view on the Lod $\backslash$ Ramleh $\backslash$ Dahmesh border area. Based on a screenshot taken from: www.govmap.gov.il

The village of Dahmesh, located on the border of the city of $\operatorname{Lod}^{2}$ in Central Israel, consists of six family compounds, home to about 600 people. The village's first families were Palestinian farmers, internal refugees ${ }^{3}$ whose lands were confiscated after the War of 1948 under the Law of Absentee Property. The families managed to prove to the Israeli authorities that they did not escape to 'enemy countries' during the war, which meant that the Law of Absentees' Property should not apply to them. ${ }^{4}$ However, in order to preempt a legal precedent of de-facto exercise of the Right of Return ${ }^{5}$, the families were instead given land in other parts of the country, usually between 10-15 percent the size of their original properties (Yacobi, 2009: chapter 5).

The Israeli planning system, developed in the first decades of the State's existence, was based on an apparatus of land designations. The lands belonging to the families of Dahmesh were marked 'agricultural', thus defining any residential buildings on them as illegal. Nevertheless, up until the early 2000's, the residents of Dahmesh continued to live on their lands and build their houses, without government interference or municipal services. At the beginning of the millennium, the regional council of Emek Lod began distributing demolition warrants to the residents of Dahmesh, opening a lengthy juridical process concerning the (un)recognition of the village as a legitimate settlement. This struggle took, and is still taking place along two parallel and interdependent legal routes. The first is the submission of a master plan for the village by the Arab Center for Alternative Planning. ${ }^{6}$ The second is the appointment of a 'Borders Committee' ${ }^{7}$ by the Ministry of Interior, mandated to examine the possibility of absorbing the village into Lod's borders and recognizing it as a neighborhood of the city.

A master plan was submitted to the local planning committee by the Arab Center for Alternative Planning in January 2007, and was rejected in 2010. In July of the same year, the plan was re-submitted, this time to the district committee, but was rejected again. The village's Residents' Committee put in a request to re-submit the master plan to the national planning committee but was also turned down. ${ }^{8}$ Parallel to this process, the Ministry of Interior appointed 
a Borders Committee, with the defined authority of examining the option to include the village as a neighbourhood in either Lod or neighbouring Ramleh. The Committee proposed not to include the village in Lod, a recommendation adopted by the then Minister of Interior Gideon Saar (Investigation Committee for the Borders of Ramleh and Lod and the Regional Council of Emek Lod: report, February 2013. hereinafter: The Borders Committee report).

On March $16^{\text {th }} 2015$, an appeal was submitted to the High Court of Justice by the Dahmesh Residents' Committee against the Israeli government, the Ministry of Interior, the Department of Land Law Compliance in the Ministry of Justice, the regional council of Emek Lod and the local planning committee of Emek Lod. The appeal asked the respondents to explain why they do not refer the question to government authorities thus acting according to the Attorney General's guidelines, which require that the issue of recognizing new settlements be decided by the cabinet. The appeal also demanded an explanation regarding the delay in

providing a solution to the problem of services and infrastructure in the village, if only temporarily(Petition for Order Nisi in Bagatz 1415435, The Dahmesh Residents Committee et al vs. the Israeli Government et al, hereinafter: the petition).

The judges' decision included a recommendation to resolve the issue by annexing Dahmesh to the city of Lod, assuming that 'the proposed solution is the most feasible one' (Bagatz 1415435, Dahmesh residents' committee et al vs. the Israeli Government et al, a decision from 16.3.15). As the city itself didn't take part in the petition, the judges demanded a response by the Lod municipality to the proposed solution, and the reconvening of the Borders Committee. A new discussion was set for September 2015. Nevertheless, the judges' verdict did not include an injunction on the demolition warrants pending against the houses in Dahmesh, and on the 15th of April three of them were demolished.

\section{The politics of decision}

A close reading of the legal documents on Dahmesh raises two central and interrelated issues: a constant argument regarding the question of authority, and the lengthiness of the juridical proceedings. In this part of the paper we will suggest to conceptualize these issues as reflecting the inherent inability to bring the matter to a close, and this inability as allowing the continuous 
presence of sovereign power in the political sphere. We will anchor this suggestion in Carl Schmitt's conceptualization of the sovereign decision.

At the opening of Political Theology (Schmitt, 2005 [1922]) Schmitt states that 'Sovereign is he who decides on the exception' (ibid, 25), thus establishing the suspension of the law as the defining action that makes sovereignty present in the political space. The concept of sovereignty as the ability to suspend law was developed by Schmitt as one of the most vigorous critics of the Weimar Republic and of the republican political structure. He accused the republic of denying the fundamental violence underlying law itself, a denial leading to a politics of legality that neutralizes its own legitimacy. Schmitt seeks to locate the foundational element of the law in a sovereignty of secularized-theological, miracle-like character, in the suspension of the legal order. The sovereign decision is such when the transition between two states - the operation and suspension of law - is not justified by law itself, but solely by the presence of the sovereign outside the legal order (though still in relation to it, being defined by its borders). Meaning, decision does not derive from the law but from the sovereign, while at the same time being the foundational action of sovereignty.

Several studies analyze the way in which sovereignty is embodied by transforming the intermediate state of the suspension of the law into the legal order itself, rendering it as constant. Many of these studies stem from Agamben's conceptualization of the camp as a space of suspended law (Agamben, 1998[1995]; Agamben, 2005[2003]). In the Israeli context, theliterature onthe occupied territories is most prominent (see Handel, 2007;Ophir and Azoulay, 2008A, and also CamiloBoano and Ricardo Marten as well as Irit Katz which engage with the application of Agamben's concept on urban spaces,. See: Boano and Marten, 2013; Katz 2015, Katz 2016). These studies focus on the occupied territories where military law prevails, territories which were never fully annexed by Israel in order to maintain the absence of an Israeli rule of law and civilian rights for the Palestinian population. In continuum to this idea of the state of exception as a sovereign practice, we suggest to think of the processes of negotiation that take place within the state of Israel par-excellence, where the rule of law applies and officially grants civilian rights to the Arab citizens. In this legal state of affairs the suspension of law is not performed widely as an official policy, but - as we will show -is created in the gaps opened and maintained between two legal potentialities. 
Schmitt's model focuses on a decision regarding the state of exception (such as a state of war), but we suggest to locate it in other forms of transformation of the existing legal state. Any room for interpretation and legal discretion allows, for example, such moments of sovereign decision that change the legal order to be applied to a particular living-space. This is due to the fact that the decision to apply a particular law on a certain living-spaces is always a sovereign act: it has no inherent validation and justification in the law itself, but solely in the sovereign's will. In such a case, the decision is the embodiment of the sovereign, but at the same time it nullifies and vanishes it from the concrete political sphere, since it allows a new legal state to takes place. Regarding Agamben's use of Schmitt, Adi Ophir describes the particular dynamic between sovereignty and law, claiming that 'Law will be released into practice only when the sovereign will retreat [...] into potentiality [...]. Sovereignty and law are entwined as communicating vessels. The release of one into practice in the retreatment of the other to its potential state' (Ophir, 2003: 363).Sovereignty therefore exists in the political sphere only in the instance of decision, of transition.

Such an understanding of the Schmittian concept of sovereign decision allows us to analyze the legal chronology of the Dahmesh unrecognition and the suspension of the decision as opening a gap between two potential spatio-legal options; recognition vis-a-vis demolition. Both opposite potentialities are legal states (assimilation into legality or the exercise of a legal warrant), of which realization will cause sovereignty to retreat to its potentiality. In analyzing this case-study, we can see how the legal debate inherently contains elements causing its inability to reach an end - the shifting of the debate to the issues of authority and length. These shifts create a prolonged negotiation which opens up an intermediate state, a space where sovereignty continues to be realized in the political sphere and refuses to retreat into potentiality, since the application of a new law is never completed.

The discussion regarding the question of authority is clearly observed in the Borders Committee report. Considering the extensive detail of the report, the Committee's recommendation is remarkably succinct: 'There is no scope for transferring the Dahmesh compound from [the jurisdiction of] Emek Lod to Lod' (The Borders Committee report, 2013: 23). The recommendation is based on the conclusions that 'the Borders Committee is not the qualified entity to decide between those alternatives... Recognizing Dahmesh as a settlement is not the 
Committee's mandate. This is a professional-political decision under the authority of the National Committee for Planning and the government' (The Borders Committee report, 2013: 22).

The petition submitted by the Residents' Committee demanded to bring the issue before the government, in accordance with the Attorney General's guidelines. The legal debate evolving from the preliminary responses deals mainly with the question of why the matter should not, in fact, be brought before the cabinet. The respondents made two preliminary responses: the first was on behalf of the Israeli Government, the Minister of Interior and the Department of Land Law Compliance (a Preliminary Response on Behalf of Respondents 1-4 in Bagatz 14l5435, The Dahmesh Residents Committee et al vs. the Israeli Government et al, hereinafter: Preliminary Response on Behalf of Respondents 1-4), and the second on behalf of the Regional Council of Emek Lod and the Local Planning Committee of Emek Lod (a Preliminary Response on Behalf of Respondents 5-6 in Bagatz 14\5435, The Dahmesh Residents Committee et al vs. the Israeli Government et al, hereinafter: Preliminary Response on Behalf of Respondents 5-6). In both responses a claim is made that the petition itself is illegitimate since it undermines the professional perspective of the planning committees that already rejected the plans requesting to acknowledge the village as a legal settlement.The responses claim that the High Court of Justice can not intervene in a decision made by the Minister of Interior, since the latter is based on a professional decision of the planning authorities.

The committees' professional perspective is thus conceived as the determining authority. In the context of an ethnocratic regime, such claims regarding the 'professionality' of the planning apparatus of the determining authority exposes how planning is used in order to depoliticize unrecognition, presenting it as based on neutral-professional opinions. The 'dark side of planning' we would suggest, is not just about understanding planning as an oppressive tool of tangible control (Yiftachel, 1994), but also about its discursive effect as a neutral and a-political apparatus (Sandercock, 1998). Furthermore, the claim regarding the decisive authority of the planning committee is contradictory to the Attorney General's guidelines, on which the petitioners rely. This constant transfer responsibility and authority exposes the inherent inability of the debate to reach an end.

The second part of the second preliminary response brings us to the other major issue reiterated in the documents: the lengthiness of the legal proceedings. This part focuses on the case-studies of three families in Dahmesh and the way they resisted the demolition warrants 
issued on their houses. The families' struggles are described as an ongoing exploitation of the legal system, and as a waste of juridical time. This description is meant to anchor the actions of the residents of Dahmesh in a context of criminal thinking sophisticatedly abusing the legal system. ${ }^{9}$ The duration of the intermediate state is also discussed in the petition itself, in a series of paragraphs entitled 'The need and justification for determining transitional provisions regarding the village at the interim period' (the petition: paragraphs 75-96). In these paragraphs, the petitioners claim that the Borders Committee should determine a ' $[\ldots]$ policy to be taken in the interim period, that is, until a final decision regarding the village is made [...]' (the petition: paragraph 75). The discussion about the need to develop a policy regarding the 'intermediate state' - that is, until the juridical proceedings take place - inherently contains the assumption that such a state is an ongoing one, a state that becomes the everyday reality of the community's life.

Reading the legal documents against the theoretical background we have suggested, allows us to claim that the inability to bring the matter to a close is inherent to the legal proceedings, and can therefore be understood as a sovereign praxis, opening a gap where new legality is not applied and the sovereign decision is never exhausted. Thus, the lack of a decision creates a continual sovereign presence in the political sphere. In the next part of the paper, we suggest a conceptualization of the kind space created by this praxis.

\section{Spaces of sovereignty}

In his essay 'Voids of Sovereignty' ${ }^{10}$ Yehuda Shenhav describes the double and contradictory sovereign action that took place in colonial spaces:

'A spatial examination of colonial history reveals the 'catch' faced by the great European empires. On the one hand, the imperial institutions sought to export the European legal order to the colonies, both in order to defend their subjects and to complete the European task of culturalization. On the other hand, they wished to escape the full annexation of the occupied territories and the complete realization of their sovereignty. The result is 'Voids of Sovereignty': partial sovereignty based on exceptions and not on an 'indivisible unity', as described by Jean Bodin. (Shenhav, 2006: 213 translated by the authors). 
Indeed, Shenhav's interpretation assumes that the annexation of occupied lands - meaning, applying the empire's laws - is the complete realization of sovereignty, thus the 'Voids of Sovereignty' are those where sovereignty is not unified, not completed. Schmitt's understanding of the sovereign decision, and the dynamic between law and sovereignty described by Ophir, leads us to reflect on this interpretation. If sovereignty exist de-facto only in the suspension of law - and while the rule of law applies sovereignty withdraws to potentiality - then we can argue that where law is not applied- sovereignty is fully present.

Based on this conceptualization we ask to use Shenhav's 'Voids of Sovereignty' and argue that in the gaps that are opened between two legal potentialities - where law is, de-facto, suspended, and an 'intermediate state' takes place - sovereignty is not being practiced partially, but fully and continuously. As we argued earlier, sovereignty does not retreat to its potentiality as long as a new legality does not take place. Furthermore, the Hebrew term for 'void' used by Shenhav suggests a double-meaning as the Hebrew word 'chalal' is meant to describe both 'space' and 'void'. In light of the discussion made in the paper thus far, we suggest to use Shenhav's term when 'chalal' is read as a space, a place, rather than a void. It is a concrete, physical place (the village), which is also a legal space. This space is the opposite of 'void', and constitutes an area in which sovereignty is fully practiced. We seek to use Shenhav's concept of 'the space of sovereignty', in the sense of both a legal and a physical space where sovereignty can be continuously practiced without retreating to potentiality. This is of significant importance to this paper, suggesting a debunking of the understanding of the Israeli urban core as a unified, stable and hermetically controlled space. The location of such 'spaces of sovereignty' shifts the question of sovereignty from the distinct frontiers such as the Negev and the West Bank to the metropolitan centre, highlighting the fact that it is essentially non-static and emphasizing the inherent inability to complete colonial projects of space-production.

This conceptualization should be understood in relation to the very nature of the Zionist project regarding space and territory, and the type of sovereign decisions made in this context. The Zionist project of occupation of space took place as a series of demolition and reconstruction acts, designed to supplant local geography with a 'new geography'. Such acts can be both physical and conceptual: the demolition of Jaffa neighborhoods surrounding Tel-Aviv, a city that was imagined to be 'born from the sands' (See Rotbard, 2005) on the one hand; and the 'normalization' of the occupied territory of Mount Hermon by re-inventing it as a Western ski 
resort (Ram, 2014) on the other. As such, the Israeli spatial project is essentially contradictory to the possibility of recognizing and legitimizing Palestinian spaces within its boundaries, since it is based on the idea of 'Judaisation' of space (Yacobi, 2009; Yiftachel, 2006). Noga Kadman, in her book On the Side of the Road and the Edges of Consciousness (Kadman, 2008), describes the methodological obliteration of 418 Palestinian villages after the War of 1948. This obliteration took place using a series of sovereign decision strategies, such as emergency regulations, occupying property by legal orders, using the British emergency orders and passing laws meant to legally establish the occupation of territories. Demolition as the basic strategy of Israeli occupation recurs in both historical and geographical research (Shay, 2002; Alexandrovitch, 2013; Yacobi, 2009, McKee, 2014). ${ }^{11}$ The nature of these actions of obliteration is of a sovereign decision about the formation of a new state of affairs, the legitimization of which does not stem from any source external to the decision itself. At the same time, the project of the replacement of geographies is never fully completed, and Palestinian spaces continue to exist in enclaves penetrating the Israeli ones. It should be emphasized that according to our reading of Schmitt, sovereign presence which appears at the moments of decision is only relevant while traces of the old geography still exist. Once the project is completed, sovereignty will retreat to potentiality and the rule of law will take its place. Yet, the obliteration is never fully accomplished, and the Israeli domination over space continues to take the form of a permanent tension between two opposite ends, between contrasting potentialities that are never fully realized(see Ophir and Azoulay, 2008B).

The inability to fully realize the demolition of Palestinian spaces is mentioned in the Borders Committee report, regarding one of the options suggested for the future of the villageits total demolition. The report mentions that 'The outcomes of such a policy are unclear and it is felt that even those who support it doubt that it will be possible to raze the compound to the ground' (The Borders Committee Report: 21). If we understand Israeli sovereignty as materialized in a state of constant suspension, of continual tension between opposing potentialities, the question arises: why the need to prevent the full obliteration of the Palestinian presence? While we understand that such obliteration is central to the creation of Israeli territory, its full realization means the completion of the project and the rendering of sovereignty in the concrete political sphere superfluous.In order to understand the refusal to decide in the case of Dahmesh-the refusal to close the gap where sovereignty is materialized in the political sphere-we 
must conceptualize the inability to complete the demolition. In the next part of the paper we will suggest to understand this inability through Schmitt's debate with Hans Kelsen's concept of the Norm.

\section{Decision and norm}

Considering the above, the question arises as to why the complete obliteration of the Palestinian space, and in this case, of the unrecognized village, cannot take place? In the context of the sovereign decision, we suggest to think of legal and political norms as constituting a restraining counter-power. These norms belong to the international context of the global West, to a selfperception of belonging to an international collective whose norms do not allow the total obliteration of the village.

The concept of the norm as a restraining factor is present is Schmitt's debate with his contemporary theoreticians, mainly with Hans Kelsen (Schmitt, 2005 [1922]: chapter 2). In Political Theology Schmitt describes decision as a reaction to the concept of the 'Ground Norm', used by Kelsen as the forming concept of any coherent legal system. The theory of the basic norm (Grundnorm), outlined by Kelsen in his seminal Pure Theory of Law (Kelsen, 1970[1934]), was aiming for the understanding of unified, coherent legal systems by tracing a chain of interrelating norms, originated in a single 'Ground Norm'. Such a norm functions as a 'Scheme of Interpretation' (ibid, 3), and it is what gives human actions their legal meaning.

A ground norm can be anchored in a tangible action such as an order or an instruction, but as a meaning it is never, at any actual moment, 'created'. Such a norm is always assumed to be external to any concrete action, and as such it is platonically ideal: '[...] the basic norm, the ultimate reason for the validity of these [legal] norms, is not created by a real will at all, but is presupposed in legal thinking' (ibid, 23). The basic norm is the carrier of a moral value, since a behavior that stands in accordance to it is considered 'good', and is based on the ethical justification of a transcendent value.

Schmitt seeks to debunk Kelsen's concept of the basic norm by suggesting that a norm cannot exist separately from a deciding sovereign persona and cannot exist as a practice without the intermediate element of the decision: 'Any legal thought transforms the legal ideal, which in its pure mode can never become actual, to a different state of affairs, while adding a moment that 
cannot be derived from the content of the legal ideal, nor from the content of any other positive legal norm' (Schmitt, 2005[1922]:51). Hence, the norm itself cannot be present in the actual political sphere without the sovereign decision to activate it, since 'legal determination as a decision norm can only instruct what should be decided, but not who should decide. [...] Therefore the question is a question of authority' (ibid, 54).

A norm, as described by Kelsen, arranges human activity ethically, since it is the ought from which every is is derived: "By "norm" we mean that something ought to be or ought to happen, especially that a human being ought to behave in a specific way' (Kelsen, 1970[1934]: 4). As such, the norm is the carrier of an ethical and moral value, since obeying the legal system deriving from it is based on collectively accepting it as just. This argument is fundamental to our discussion since the un-realization of the total obliteration of Palestinian presence - or as we see it-the non-exhaustion of sovereign decision and the incompletion of the project of Israeli new geographies - can be seen as based on a restraining normative system of the international context. In other words, full obliteration cannot be realized since the norms of the international community will not allow it.

While we acknowledge the partiality of the identification of the norm with universal legal and moral values, we wish to emphasize the ways the Israeli legal system identifies itself as based on the norms of western morals. In this context, the common Israeli narrative of the 'villa in the jungle' (Bar Yosef, 2014) comes to mind. Questions of morality and normative behaviour often appear in the Israeli public discourse regarding the Palestinians, when the clearest example is the question of the army's morality and 'the purity of weapon'. Another example of the norm as a restraining factor can be found in the discourse around 'punitive demolitions' of Palestinian houses, the engineering procedure conducted in order to avoid damage on neighbouring houses and the occasional choice made to 'merely' block the house or some of the rooms as a more moderate punishment. The action of demolition in this case is constantly under negotiation in terms of visibility of proportionality and restraint

The international context reveals that the norm, imaginary as it is, is a meaningful agent in the political sphere, a restraining element that makes the obliteration of the village an option that 'even those who support it doubt' the possibility of its realization. Such an understanding renders the suspended space of unrecognition to a space of tension between legal 'ethical' norm, and a sovereign decision denying the existence of transcendent values. This interpretation 
suggests that decision and norm are in constant negotiation. Such negotiation creates a state of affairs in which extreme contradicting actions take place randomly in different locations and in different points in time. On the one hand, houses and villages do get occasionally demolished; on the other, formal reservations regarding the ability to demolish, such as the one expressed in the Borders Committee report, are occasionally made. A constant uncertainty, caused by stalemate in legal processes and contingency of house demolitions, is inherent to such state of negotiation between decision and norm.

To conclude this section, the Dahmesh case adds another layer to the understanding of sovereignty as produced and re-produced through its dynamics with material space. 'Normative' behaviour, based on liberal ethical assumptions, is a condition to international recognition in the sovereignty of the state of Israel. This case-study therefore allows, once again, undermining the apparent unity of the sovereign power, pointing at the various ways it is shaped and represented in different contexts.

\section{Conclusions}

Throughout this paper we have examined the case study of the unrecognizes Palestinian village of Dahmesh through the Schmittian conceptual prism of sovereignty. We have shown how the maintenance of a gap between two different legal states creates an enduring stalemate, a state where a new legality is not applied and sovereignty does not withdraw to its potentiality. This stalemate, we conclude, is achieved by the constant transfer of authority to decide between the political and professional governmental bodies, and by the lengthiness of the legal proceedings. Thus, unrecognition of Palestinian villages and neighborhoods are part of an apparatus operating for the constant embodiment of Israeli colonial sovereignty. We have conceptualized the spaces produced through this practice as 'spaces of sovereignty', namely spaces where sovereignty is

fully and continuously practiced. In presenting Schmitt's argument with Kelsen's concept of the legal norm we have illustrated how these spaces exist in a constant tension between practices of obliteration that are central to Israeli space production and international norms preventing complete demolition.

Our discussion frames the concept of sovereignty in the spatial context, conceptualizing it as a force meant to realize and materialize a hegemonic national narrative on space, in this 
context - the Zionist narrative of 'a land with no people to a people with no land'. Framing sovereignty as constructing space according to national ideology, allows for the understanding of the ways sovereign power constantly reproduces itself through the reproduction of space. The location of the case study within the Tel-Aviv metropolis indicates the constant instability of hegemonic spaces where the Zionist project was allegedly completed, spaces which are not considered as being in conflict in the national context.Indeed, we conclude, the location of undecided spatial issues and suspended spaces in the Tel-Aviv metropolis challenges the assumption that the imposition of hegemonic narratives on space can be completed.

Furthermore, the case of Dahmesh should be seen as part of a wider phenomenon. Cases such as Tel-Aviv's neighborhoods which were built on Palestinian villages and whose legal status remain unsettled, or 'temporary' olive groves planted in Jaffa in order to prevent the rebuilding of houses and markets, should be understood as spaces of negotiation where sovereignty continues to be reproduced and re-approved. Our analysis throughout this paper can thus be used as a conceptual platform for research aiming to bring the discussion on sovereignty from the edges of hegemonic spaces to the heart of urban centers in Israel, subverting the imagined stability of hegemony itself. In the international context, this critique can be used to examine practices of re-invention and re-creation of political geographies in different cases of settler societies.

On the other side of the legal battle, the refusal to decide plays a major role in the acts of resistance taken by the residents of Dahmesh. In this final section of the paper we offer some thoughts for possible future research regarding resistance. The preliminary response on behalf of respondents 5-6 refers to the way three families used legal means in order to prevent the demolition of their houses as a systematic exploitation of the legal system. Through the perspective of resistance, we suggest to refer to such 'exploitation' as a possibility to maintain informal ways of life in the borders of the 'space of sovereignty'. Resistance takes place by using the same set of tools used by the sovereign - the constant postponement of the decision.

The resistance potential of the withdrawal of the legal procedures is revealed in the petition itself, under the paragraphs referring to 'The need and justification for determining transitional provisions regarding the village at the interim period' (the Petition: paragraphs 7596). The petition demands to determine provisions regarding '[...] the state of the village in the 
intermediate period, including provisions of infrastructure and services and policies regarding the un-authorized structures' (the Petition: paragraph 84). The petition defines the 'interim period' as the time lasting '[...] until a final decision regarding the village will be made, either by recognizing it or annexing it to the city of Lod' (the Petition: paragraph 76), not including the option of demolition as a potential decision. The main claim made by the petition is that the absence of transitional provisions - following the recommendations of the Borders Committee, determining only what needn't be done and not what needs to be done - harms the village residents since it allows the local council of Emek Lod to continue the demolitions. The petition states that the council ' $[. .$.$] interprets [...] the Borders Committee's recommendations as a 'green$ light' to renew its activities to demolish the houses [...] and not to provide infrastructure and services to the residents' (the Petition: paragraph 83).

The activities carried out in order to promote demolitions are in fact local exercises of sovereign decisions, legitimated by a presumed future decision. These actions can also serve as a catalyst for such a decision since 'the demolition of structures will prevent the recognition of the village' (the Petition: paragraph 86). In contrast, the petition promoted the opposite estimated alternative - the recognition of the village - in order to justify the demand 'to allow the provision of infrastructure and services and the freezing of legal proceedings against the existing structures' (the Petition: paragraph 96).

The lengthening of the intermediate state is thus turning both into a tactic of survival and a practice of resistance. It is a tactic of survival since the intermediate state legitimizes the demand to freeze the demolition warrants. But it is also a practice of resistance to the very legitimization of the law these warrants represent. The exhaustion of the sovereign decision means either the demolition of the village or its assimilation into a legal order legitimated by a certain sovereign. Resistance in the form of a constant postponement of the legal proceedings in fact widens the 'space of sovereignty' and represents resistance to both binary alternatives demolition on the one hand, and assimilation to the legal order legitimized by the occupying sovereign on the other.

To sum up we would suggest that this mode of resistance is responding tothe lack of a basic need for shelter but its visibility, scope and inability to be restrained are repeatedly regarded by the authorities. Another observation of the wide dimensions of unrecognized construction reveal it not merely as a residential solution - which can be found in nearby cities 
such as Ramleh and Lod - but as one of the aspects of resistance. This aspect exceeds the binary opposition of resistance and non-resistance as expressing either collective protest or passivity. What we offer as a starting point for future studies (following James Scott, 1985 and Assef Bayat, 2000), is to recognize the origins and potentiality of a resistance based on existing social networks and the subversive use of the sovereign's own legal apparatus.

\section{Epilogue}

The relevance of discussing sovereignty and informality within settle colonial context has been validated recently. In January 2017, while we were revising this paper for publication, the unrecognized Bedouin village of Umm Al-Hiran in the Negev was evicted and demolished, in order to build a Jewish settlement in its territory. The land of Umm Al-Hiran was allotted by the state to the Bedouin tribe of Abu Alkian - moved by the Israeli military from their original lands - in the 1950's, for agricultural purposes. In 2002 a plan for the establishment of 14 new Jewish settlements in the Negev was approved, and eviction warrants were issued to the residents of Umm Al-Hiran. The residents of the village filed a petition against the plan, but after a long legal struggle, early in the morning of January $18^{\text {th }}, 2017$, the village was demolished. A short while after the eviction and demolition of Umm Al-Hiran, on the $1^{\text {st }}$ of February, another eviction took place: the one of Amona, an illegal Jewish settlement built on private Palestinian lands in the occupied territories, following an order issued by the Supreme Court. The eviction was violent, injuring about sixty police officers that were hurt by stones thrown and bleach sprayed at them by the settlers who barricaded in the settlement's Synagogue. Both these evictions, of Bedouins in the Negev and of Jewish settlers in the occupied territories, represent the tension we have referred to in this article, between the sovereign decision -erasing the Bedouin living-space for the production of new, invented, Jewish geographies - and the necessity to comply to international ethics, represented by the Supreme Court's order to evict Amona. The pairing of these events, linked together in a balancing force, exposes the stagnation inherent to the state of tension between decision and norm, and the inherent inability of the Israeli-Palestinian conflict to come to an end under those circumstances. 


\section{References}

Agamben G (1998 [1995]) Homo Sacer: Sovereign Power and Bare Life. Stanford: Stanford University Press.

Agamben G (2005 [2003]) State of Exception. Chicago: Chicago University Press.

Alexandrovich O (2013) Civilian Demolition: The Planned Abolition of Manshiah Neighborhood in Jaffa, 1948-1949. Studies on the Revival of Israel23: 247-314. (Hebrew)

Bar-Yosef, E (2014)A Villa in the Jungle: Africa in Israeli Culture. Tel Aviv: Ha'kibbutz Ha'meuchad. (Hebrew)

Bayat A (2000) From 'dangerous classes' to 'quiet rebels': the politics of the urban subaltern in the global South. International Sociology 15.3: 533-57.

Boano C and Marten R (2013) Agamben's Urbanism of Exception: Jerusalem's Border Mechanics and Biopolitical Strongholds [electronic version].Cities 34, Retrieved from: http://www.sciencedirect.com/

Braverman I (2006) Illegality in East Jerusalem: Between House Demolition and Resistance. Theory and Criticism 28 (Spring):11-42. (Hebrew)

Cohen H (2000) The Present Absentees: Internal Refugees in Israel Since 1948. Jerusalem: Van Leer Institute. (Hebrew)

Fenster T (2012)Who's City is it? Planning, Knowledge and Everyday Life. Tel Aviv: Ha'Kibbuz Ha'Meuchad - Urban Red Line. (Hebrew)

Foucault M (1991 [1975]) Discipline and Punish: The Birth of the Prison. London: Penguin Books.

Hendel A (2007) Controlling Space with Space: Uncertainty as Controlling Technology. Theory and Criticism31 (Winter): 101-126. (Hebrew)

Katz, I (2015) Spreading and Concentrating: the Camp as the Space of the Frontier. City 19(5): 722-735. 
Katz, I (2016) Camp evolution and Israel's creation: between 'state of emergency' and 'emergence of state'. Political Geography 55: 144-155.

Kedar A (1998) A Time of Majority, A Time of Minority: Land, Nation and Prescription Law in Israel. Studies in Law21: 665-746. (Hebrew)

Kedman N (2008) At the Sides of the Road and the Edges of Consciousness: The Expulsion of Palestinian Villages Emptied in 1948 Out of the Israeli Discourse. Jerusalem: November Books. (Hebrew)

Kelsen H (1970 [1934]) Pure Theory of Law. Berkeley: University of California Press.

McKee E (2014) Performing Rootedness in the NegevlNaqab: Possibilities and Perils of Competitive Planting. Antipode 46(5):1172-1189

Ophir A (2003) Between the Sanctification of Life and Their Abandonment: Instead of an Introduction to Homo Sacer. in: Lavie S (ed.) Technologies of Justice: Law, Science and Society. Tel Aviv: Ramot. (Hebrew)

Ophir A and Azoulay A (2008A) This Regime Which is Not One: Occupation and Democracy Between the Sea and the River (1967-). Tel Aviv: Resling. (Hebrew)

Ophir A and AzoulayA (2008B) The Monster's Tail [electronic version]. Roulotte 5. Retrieved from: http://www.roulottemagazine.com

Ram M (2014) White But Not Quite: Normalizing Colonial Conquest Through Spatial Mimicry. Antipode 46(3): 736-753.

Roded B (2012) Planning in a State of Non-Decision: The Case of the Negev. Planning 9(1): 141-164. (Hebrew)

Rotbard S (2005) White City, Black City. Tel Aviv: Babel. (Hebrew)

Roy A (2005) Urban Informality: Toward an Epistemology of Planning. Journal of the American Planning Association 71: 147-158. 
Roy A (2011) Slumdog Cities: Rethinking Subaltern Urbanism. International Journal of Urban and Regional Research 35.2: 223-38.

Sandercock L (1998). Towards Cosmopolis. New Jersey: Wiley.

Schmitt C (2005[1922]) Political Theology. Tel Aviv: Resling. (Hebrew)

Scott J C (1985)Weapons of the Weak - Everyday Forms of Peasant Resistance. New Haven and London: Yale University Press.

Shay A (2002) The Destiny of Abandoned Arab Villages at the Eve of The Six-Days-War and After.Cathedra105 (September): 151-170. (Hebrew)

Shenhav Y (2006) Spaces of Sovereignty, the Exceptional and the State of Exception: Where Did the Imperial History Go? Theory and Criticism 29 (Fall): 205-218. (Hebrew)

Tzfadia E and Yiftachel O (2014) The'Gray' City of Tomorrow. in: Fenster T and Shlomo O (eds.) Cities of Tomorrow - Planning, Justice and Sustainability Today. Tel Aviv: Ha'Kibbutz Ha'meuchad, pp.176-192. (Hebrew)

Veracini L (2010) Settler Colonialism: A Theoretical Overview. London: Palgrave Macmillan.

Weizman E and Sheikh, F(2015)The Conflict Shoreline: Colonization as Climate Change in the Negev Desert. Göttingen: Steidl.

Wolfe P (2006) Settler colonialism and the elimination of the native. Journal of Genocide Research 8(4): 387-409.

Yiftachel O (2006) Ethnocracy: Land and Identity Politics in IsraeNPalestine.Philadelphia: University of Pennsylvania Press.

Yiftachel O (1994) The Dark Side of Modernism: Planning as Control of an Ethnic Minority. In: Watson S and Gibson K (eds.). Postmodern Cities and Spaces. Oxford: Basil Blackwell.

Yacobi H (2009)The Jewish-Arab City: Spatio-Politics in a Mixed Community. London: Routledge. 
Petition for Order Nisi in Bagatz 14 15435 , The Dahmesh residents committee et al vs. the Israeli Government et al.

A Preliminary Response on Behalf of Respondents 1-4 in Bagatz 1415435, The Dahmesh residents committee et al vs. the Israeli Government et al.

A Preliminary Response on Behalf of Respondents 5-6 in Bagatz 14I5435, The Dahmesh residents committee et al vs. the Israeli Government et al.

Bagatz 5435\14, The Dahmesh residents committee et al vs. the Israeli Government et al, Decision from 16.3.15.

Investigation Committee for the Borders of Ramleh and Lod and the Regional Council of EmekLod: Report, February 2013.

The Attorney General Guidelines, Decisions Regarding the Foundation of New Settlements, 1.1800, 2004.www.govmap.gov.il

${ }^{1}$ At this early stage we should clarify our use of terminology, without entering into the controversy over terms, which is beyond the scope of this paper. 'Arab' and 'Palestinian' are interchangeable terms in the paper, denoting residents of Israel/Palestine who belong to the Arab culture. There is a political distinction between Arab citizens of Israel (the area within the internationally recognized pre-1967 borders) and Arabs residing in the Occupied Territories, but the ethno-national identity of both is Palestinian-Arab.

${ }^{2}$ Lod (in Arab: Al-Lydd) is a city in the Central district of Israel, South east of Tel-Aviv. Archeologists assess the city to be about 8,000 years old. Today it is a mixed Arab-Jewish city with a population of about 72,000 people, and is socially-economically rated $4 \backslash 10$. For a detailed study of the spatio-politics of the city see: Yacobi, 2009.

${ }^{3}$ Internal Refugees is a term used to define the Palestinian population that was expelled from its original property and moved to other parts of the country (Cohen, 2000).

${ }^{4}$ This case is an exceptional one, though we know that as part of the authorities' policies, some families migrated from Shech Munis and the Triangle area, receiving compensation of agricultural lands around Lod, amounting to between 10 and 15 percent of the confiscated lands. This matter arises from a statement given by the Kishak family living in Lod (a statement given 
to Nicola Sabba, attorney, 15.1.1999). For more information see: Yacobi, 2009. Information regarding the families of Dahmesh was given in an informal conversation with attorney Kayes Nasser.

${ }^{5}$ The Right of Return is the claim made demanding to allow Palestinians who were deported from their lands during the war of 1948 to reclaim their property. It is a major, controversial issue in the Israeli-Palestinian conflict.

${ }^{6}$ The Arab Center for Alternative planning is a non- governmental organization active in Israel since the early millennium. The organization represents the Arab population in Israel in issues of planning, through the development of master plans, representations in courts and committees and through research. The organization's website: http://www.ac-ap.org

${ }^{7} \mathrm{~A}$ Borders Committee is an investigation committee composed of experts, appointed in order to decide on alterations to municipal borders.

${ }^{8}$ All chronological details are the result of cross-referencing the information in the documents examined in this article.

${ }^{9}$ The foundation of the concept of delinquency in this context is a common practice regarding discrimination in planning. Irus Braverman (Braverman, 2006) refers extensively to the concept of 'criminality' as part of the manufacturing of illegality: 'One of the main characters of illegality manufactured in the legal route is the criminal labeling resulting from its application. Some of the government officials we interviewed believe that the phenomenon of illegal structures originates in economic delinquency. For example, a former mayor's counsel notes: They practically light the legal path with a projector... but [...] the Arabs prefer the cheap and fast way. [But] as soon as this simple delinquency being caught, it is wearing a political cloak and recruits... the little girl with braids crying [over] her ruined house' (Braverman, 2006: 29). More on this subject see: Yacobi, 2009.

${ }^{10}$ In Hebrew the same word is used to describe 'space' and 'void'. This double-meaning is essential to the understanding of our conceptualization here.

${ }^{11}$ In the scope of this article we will not be able to discuss house demolition as a sovereign performance trough Foucault's writing of punitive practices (Foucault, 1991[1975]).For a detailed discussion see: Braverman, 2006. 